\title{
Encontros com a crítica
}

\author{
Thiago S. Venanzoni' \\ I - USP
}

São Paulo (SP), Brasil

\section{LOPES, D.}

Afetos, relações e encontros com

filmes brasileiros contemporâneos.

São Paulo: Hucitec, 2017, 200 p.

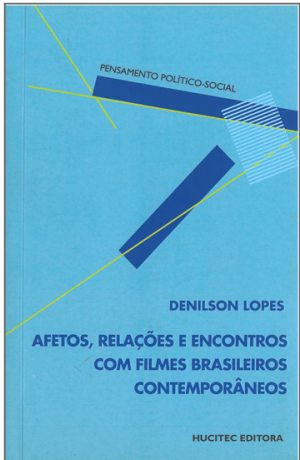

Resumo: O mais recente livro lançado por Denilson Lopes, professor associado da Escola de Comunicação da UFRJ, propõe-nos um debate em relação à crítica, no objeto que lhe é caro, o cinema. Porém, há em seus ensaios, fazendo referência às suas predileções, algo que cabe às obras audiovisuais de forma mais ampliada, e que está na ordem do afeto, das imagens e seus circuitos, e dos encontros que a crítica pode nos oferecer com as obras.

Palavras-chave: afetos; crítica; cinema brasileiro contemporâneo; imagem audiovisual; queer

Abstract: Meetings with the critique - The most recent book by Denilson Lopes, associate professor at the School of Communication of UFRJ, proposes a debate in relation to critique of the object — which is dear to him — the cinema. However, there is in his essays — in reference to his predilections - something that belongs to audiovisual works in a broader way, which is in the order of affection, images and their circuits, and in the encounters that critique can offer us with the works.

Keywords: affect; criticism; contemporary brazilian cinema; audiovisual image; queer

Em carta escrita ao cineasta Leonardo Mouramateus, uma mensagem que só chega ao destinatário e a nós como parte introdutória a este livro, o autor faz relato da eterna 
inconsistência e, da mesma maneira, presença da crítica. Parece haver uma instância do tempo irreconciliável, ou, como ele próprio descreve: "O livro me escapa. Parece mesmo que ele perde seu tempo, seu momento" (LOPES, 2017, p.17). A crítica, e os afetos, também se encontram nessa (a)temporalidade, se assim podemos nomear. Os atos analítico e descritivo são igualmente compreendidos como um tempo fugaz, algo candente em um determinado momento que escapa no minuto seguinte. Não obstante, portanto, a crítica vale-se como um exercício ao não se resumir ao momento do encontro com a obra, com premissas e prognósticos, mas em tempo expandido, em que as imagens ocupam-se de dizer. Um encontro como a fagulha afetiva que anseia a escrita.

A grande questão, diante desse emblema que o livro apresenta, não é redigir bem algo sobre aquilo que lhe é objeto, mas reconhecer as perguntas a serem feitas aos objetos. Para Denilson Lopes, uma crítica que não se prende a nada além de aspectos de uma tradição da cinefilia responde apenas a determinados anseios e demandas, mas não compreende "o que a imagem pode dizer da vida presente" (idem, p.22) ao trocar as imagens por categorias, diretores, aspectos fílmicos diversos. Como sugere o título do seu livro, seu texto se baseia no encontro. E nas imagens que mobilizam à crítica.

Estamos diante, assim, de algo pouco cultivado no âmbito da crítica audiovisual e se procura, portanto, uma revisão em relação a isso: a questão da imagem. De forma gradual, assim nos parece, esse debate vai ganhando lastro mas, da maneira que o autor nos coloca, mais do que ser um elemento a mais da crítica, ou seja, além de tudo isso tem a imagem, seja a imagem o que mobiliza o afeto, o encontro e a própria crítica. O debate se inscreve, assim, no cinema brasileiro como sintoma dessa crítica que emerge como campo ao se olhar as obras audiovisuais. Contribui para isso o momento contemporâneo em que vive o cinema nacional, suas obras de reunião e produção coletiva, o debate sobre visibilidade e reconhecimento, e o contexto político do país do lulismo e do pós-lulismo. Entretanto, não se procura no livro, afirma o autor, identificar um período histórico do cinema brasileiro.

Ao pensar em uma dinâmica anticíclica do cinema atribui-se a este momento também um sintoma renovado sem precedentes concretos na história do cinema brasileiro e, portanto, restrito em suas comparações ao que já foi realizado no Cinema Novo ou no, assim chamado, Cinema da Retomada. Faz-nos crer que o encontro da crítica com os filmes, nessa perspectiva, se dá como um afeto renovado de apreensão ao que se coloca hoje em demanda no país, ao que se apreende sociologicamente na cultura nacional e fora do Brasil, em um estado novo de espírito e do tempo. Interessante também refletir, e o livro nos auxilia a pensar, em como a escrita, seja ela em qual situação se apresenta, está sempre envolvida pelos afetos carregados por quem é seu autor. Essa dinâmica está transparente no próprio texto de Denilson Lopes, quando ele assume esse papel subjetivo, e também opaco quando se coloca, indiretamente, como um observador - para pensar como Crary, um sujeito ativo - das obras e agente das afeições mobilizadas por elas. O mesmo 
pode ser dito em relação a esta resenha. Isso se deve, sobretudo, ao que o autor descreve no segundo capítulo do livro, e às viradas epistemológicas ocorridas em meio século XX.

Entre todos os movimentos ocorridos, como a virada linguística (linguist turn), virada cultural (cultural turn) e mais recentemente o que se nomeia como gender turn, ou estudos de gênero, a que salta mais em importância na visão do autor é a virada afetiva ou Affect Theory. Ao dar protagonismo ao campo de discussão em torno do conceito e teorias do afeto, Lopes aposta na competência desse campo em "fazer emergir questões que sem essa nomenclatura ficariam silenciadas ou pouco visíveis" (LOPES, 2017, p.34). O livro acredita, em sentido ampliado, que pensar no afeto como movimento do encontro entre o sujeito e a obra, e a crítica, é sair de determinados discursos totalizantes em voga até pouco tempo, que faziam lugar na explicação de um mundo de experiência limitada ou na ausência total da experiência. Impossível também não se referir à picture turn ou virada pictórica defendida por W.J.T. Mitchell (2015) e tornar protagonista a imagem e seus desejos de vivência.

Neste percurso emerge também a pergunta central da obra, para qual o autor busca respostas ao mesmo tempo em que constrói o astrolábio dos mares imemoriais: "em que medida a discussão sobre os afetos que vêm desde Spinoza até os estudos de gênero (gender) coloca questões para a arte?" (ibidem, p.34). Essa pergunta talvez seja a mais fácil de identificar, diante das várias formas de encarar as obras audiovisuais hoje em dia em face às redes sociais e sua, assim referida, democratização das falas, porém a mais complexa de ser respondida pelo mesmo motivo que se aparenta como premissa, ou seja, o falatório provocado pela assunção de vozes. Encara-se, entretanto, tudo isso como um processo da cultura e que deve ser levado sempre em consideração, ainda que seja para relativizar ou efetivamente incorporar à crítica.

Outra demanda que se mostra, e o livro questiona, é a fuga à abstração como resposta que, com uma certa frequência, a academia opta ao fazer suas considerações. Uma maneira de diferenciação, podemos dizer. Assim como o livro, acredita-se também que há uma forma complexa de criticar que não faça uso da abstração como um expediente a ser valorizado. Pretende-se, assim, reconhecer uma crítica que fale para mais pessoas, sem perder sua razão, seu sentido e suas formulações. O caminho escolhido pelo autor e pelo livro é pensar em afetos pictóricos como explicação que suspende a leitura fílmica que caminha pela trilha do cinema clássico e do cinema moderno. Ou seja, a centralidade da imagem é a aposta para a descrição de um cinema que localiza no encontro, no afeto, suas potencialidades.

As obras audiovisuais escolhidas pelo autor para as descrições e análises são, Transeunte, filme de 2010 dirigido por Eryk Rocha, objeto central do capítulo três do livro, intitulado "O homem que caminha sem chegar"; Adormecido, de Clarissa Campolina, curta-metragem de 2011, é o objeto do quarto capítulo, "O fim das paisagens"; o quinto capítulo traz uma construção social e contextual a partir de filmes que retratam as cidades, entre eles $O$ som ao redor (2013), de Kléber Mendonça Filho, de Pedro Aspahan, Matéria de composição (2013), e HU (2011), de Pedro Urano \& Joana Traub Csekö, "entre outros 
filmes, como contraponto a um discurso modernizador que retorna" (LOPES, 2017, p.79). Porém, o filme central é de Lucia Murat, Histórias que só existem quando lembradas (2011), obra pela qual o autor imagina a já referida paisagem contemporânea do cinema brasileiro, em capítulo intitulado "Ruínas pobres, cidades mortas". O sexto capítulo é uma análise de Estrada para Ythaca (2010), de Luiz Pretti, Ricardo Pretti, Guto Parente \& Pedro Diógenes, e um dos projetos do coletivo cearense Alumbramento. Inicia-se então um debate sobre o eterno retorno da sociedade brasileira e a condição do fracasso como algo para-além de uma atmosfera negativa que ele carrega, intitulado "O alumbramento e o fracasso".

O capítulo sete, intitulado "De volta à festa", talvez um dos mais subjetivos do livro, apresenta as afeições do autor por filmes diversos, em encontros das mais variadas ordens. Remete-se a um caráter da escrita crítica proposta, que não se resume a descrições bem feitas, propriamente; já no oitavo capítulo, Lopes retorna ao início e volta ao diálogo com Leonardo Mouramateus a partir de seu filme $A$ festa e os cães (2015), em capítulo intitulado "O cosmopolitismo nos pequenos gestos". Retoma também um debate sobre a imagem e a experiência do seu encontro. O nono capítulo, "Afeto queer", é um dos mais importantes do livro. Nele discute algo que é cada vez mais presente no debate sobre a arte no Brasil, e as dimensões do queer nas instâncias de afeto, algo que pode dimensionar de outro modo um renovado tipo de análise a essas variadas produções contemporâneas que se encontram na cultura. No último capítulo, "O retorno do artifício", Lopes persiste com debate sobre o queer e questões LGBTQ, de certa forma, mas inicia outros questionamentos sobre o real ou os realismos. A importância desse capítulo, assim podemos avaliar, está em desconstruir certas premissas do debate da representação a partir de algumas obras elencadas.

Faz compreender que essas inconstâncias dos encontros, e dos afetos, não permite que nos tornemos fixos em ideias recorrentes e, ao contrário, busquemos caminhos para a crítica. Essa, por fim, parece ser a grande função, chave, da fechadura que o livro resiste em abrir.

Thiago S. Venanzoni é doutorando pela ECA/USP no PPGMPA, com bolsa Capes. É pesquisador do Grupo de Estudos da Linguagem: Práticas Midiáticas (MidiAto).

thiago.venanzoni@gmail.com

\section{Referências}

CRARY, J. Técnicas do observador: visão e modernidade no século XIX. Rio de Janeiro: Contraponto, 2012.

LOPES, D. Afetos, relações e encontros com filmes brasileiros contemporâneos. São Paulo: Hucitec, 2017.

MITCHELL, W.J.T. O que querem as imagens? In ALLOA, E. (org.). Pensar a imagem. Belo Horizonte: Autêntica, 2015. 